\title{
Neuropeptide W/neuropeptide B receptors (version 2019.4) in the IUPHAR/BPS Guide to Pharmacology Database
}

\author{
Anthony P. Davenport ${ }^{1}$, Janet J. Maguire ${ }^{1}$ and Gurminder Singh ${ }^{1}$
}

1. University of Cambridge, UK

\begin{abstract}
The neuropeptide BW receptor 1 (NPBW1, provisional nomenclature [5]) is activated by two 23-amino-acid peptides, neuropeptide W (neuropeptide W-23) and neuropeptide B (neuropeptide B-23) [20, 6]. C-terminally extended forms of the peptides (neuropeptide W-30 and neuropeptide B-29) also activate NPBW1 [2]. Unique to both forms of neuropeptide $\mathrm{B}$ is the $\mathrm{N}$-terminal bromination of the first tryptophan residue, and it is from this posttranslational modification that the nomenclature NPB is derived. These peptides were first identified from bovine hypothalamus and therefore are classed as neuropeptides. Endogenous variants of the peptides without the $\mathrm{N}$ terminal bromination, des-Br-neuropeptide B-23 and des-Br-neuropeptide B-29, were not found to be major components of bovine hypothalamic tissue extracts. The NPBW2 receptor is activated by the short and Cterminal extended forms of neuropeptide $\mathrm{W}$ and neuropeptide $\mathrm{B}$ [2].
\end{abstract}

\section{Contents}

This is a citation summary for Neuropeptide W/neuropeptide B receptors in the Guide to Pharmacology database (GtoPdb). It exists purely as an adjunct to the database to facilitate the recognition of citations to and from the database by citation analyzers. Readers will almost certainly want to visit the relevant sections of the database which are given here under database links.

GtoPdb is an expert-driven guide to pharmacological targets and the substances that act on them. GtoPdb is a reference work which is most usefully represented as an on-line database. As in any publication this work should be appropriately cited, and the papers it cites should also be recognized. This document provides a citation for the relevant parts of the database, and also provides a reference list for the research cited by those parts.

Please note that the database version for the citations given in GtoPdb are to the most recent preceding version in which the family or its subfamilies and targets were substantially changed. The links below are to the current version. If you need to consult the cited version, rather than the most recent version, please contact the GtoPdb curators.

\section{Database links}

Neuropeptide W/neuropeptide B receptors

http://www.guidetopharmacology.org/GRAC/FamilyDisplayForward?familyld=45

Introduction to Neuropeptide W/neuropeptide B receptors

http://www.guidetopharmacology.org/GRAC/FamilylntroductionForward?familyld=45 


\section{Receptors}

NPBW1 receptor

http://www.guidetopharmacology.org/GRAC/ObjectDisplayForward?objectld=303

NPBW2 receptor

http://www.guidetopharmacology.org/GRAC/ObjectDisplayForward?objectld=304

\section{References}

1. Baker JR, Cardinal K, Bober C, Taylor MM and Samson WK. (2003) Neuropeptide W acts in brain to control prolactin, corticosterone, and growth hormone release. Endocrinology 144: 2816-21 [PMID:12810535]

2. Brezillon S, Lannoy V, Franssen JD, Le Poul E, Dupriez V, Lucchetti J, Detheux M and Parmentier M. (2003) Identification of natural ligands for the orphan G protein-coupled receptors GPR7 and GPR8. J. Biol. Chem. 278: 776-83 [PMID:12401809]

3. Dun SL, Brailoiu GC, Mizuo K, Yang J, Chang JK and Dun NJ. (2005) Neuropeptide B immunoreactivity in the central nervous system of the rat. Brain Res. 1045: 157-163 [PMID:15910774]

4. Dun SL, Brailoiu GC, Yang J, Chang JK and Dun NJ. (2003) Neuropeptide W-immunoreactivity in the hypothalamus and pituitary of the rat. Neurosci. Lett. 349: 71-4 [PMID:12946555]

5. Foord SM, Bonner TI, Neubig RR, Rosser EM, Pin JP, Davenport AP, Spedding M and Harmar AJ. (2005) International Union of Pharmacology. XLVI. G protein-coupled receptor list. Pharmacol. Rev. 57: 279-88 [PMID:15914470]

6. Fujii R, Yoshida H, Fukusumi S, Habata Y, Hosoya M, Kawamata Y, Yano T, Hinuma S, Kitada C and Asami T et al.. (2002) Identification of a neuropeptide modified with bromine as an endogenous ligand for GPR7. J. Biol. Chem. 277: 34010-6 [PMID:12118011]

7. Guerrero M, Urbano M, Wang Z, Zhao J, Velaparthi S, Schaeffer MT, Brown SJ, Saldanha SA, Chase P and Ferguson J et al.. (2010) Optimization and Characterization of a Second Antagonist for G-protein Coupled Receptor 7 (GPR7) Probe Reports from the NIH Molecular Libraries Program[PMID:23762933]

8. Guerrero M, Urbano M, Wang Z, Zhao J, Velaparthi S, Schaeffer MT, Brown SJ, Saldanha SA, Chase P and Ferguson J et al.. (2010) Optimization and Characterization of an Antagonist for G-Protein Coupled Receptor 7 (GPR7) Probe Reports from the NIH Molecular Libraries Program[PMID:22834040]

9. Ishii M, Fei $H$ and Friedman JM. (2003) Targeted disruption of GPR7, the endogenous receptor for neuropeptides $\mathrm{B}$ and $\mathrm{W}$, leads to metabolic defects and adult-onset obesity. Proc. Natl. Acad. Sci. U.S.A. 100: 10540-5 [PMID:12925742]

10. Kanesaka M, Matsuda M, Hirano A, Tanaka K, Kanatani A and Tokita S. (2007) Development of a potent and selective GPR7 (NPBW1) agonist: a systematic structure-activity study of neuropeptide B. J. Pept. Sci. 13: 379-85 [PMID:17486669]

11. Lee DK, Nguyen T, Porter CA, Cheng R, George SR and O'Dowd BF. (1999) Two related G proteincoupled receptors: the distribution of GPR7 in rat brain and the absence of GPR8 in rodents. Brain Res. Mol. Brain Res. 71: 96-103 [PMID:10407191]

12. Levine AS, Winsky-Sommerer R, Huitron-Resendiz S, Grace MK and De Lecea L. (2005) Injection of neuropeptide W into paraventricular nucleus of hypothalamus increases food intake. Am J Physiol Regul Integr Comp Physiol. 288: R1727-R1732 [PMID:15886360]

13. Mazzocchi G, Rebuffat P, Ziolkowska A, Rossi GP, Malendowicz LK and Nussdorfer GG. (2005) G protein receptors 7 and 8 are expressed in human adrenocortical cells, and their endogenous ligands neuropeptides B and w enhance cortisol secretion by activating adenylate cyclase- and phospholipase Cdependent signaling cascades. J. Clin. Endocrinol. Metab. 90: 3466-71 [PMID:15797961]

14. Mondal MS, Yamaguchi H, Date $Y$, Shimbara T, Toshinai $K$, Shimomura $Y$, Mori M and Nakazato M. (2003) A role for neuropeptide W in the regulation of feeding behavior. Endocrinology. 144: 4729-4733 [PMID:12959997]

15. Motoike T, Long JM, Tanaka H, Sinton CM, Skach A, Williams SC, Hammer RE, Sakurai T and Yanagisawa M. (2016) Mesolimbic neuropeptide W coordinates stress responses under novel 
environments. Proc. Natl. Acad. Sci. U.S.A. 113: 6023-8 [PMID:27140610]

16. Nagata-Kuroiwa R, Furutani N, Hara J, Hondo M, Ishii M, Abe T, Mieda M, Tsujino N, Motoike T and Yanagawa $Y$ et al.. (2011) Critical role of neuropeptides B/W receptor 1 signaling in social behavior and fear memory. PLoS ONE 6: e16972 [PMID:21390312]

17. O'Dowd BF, Scheideler MA, Nguyen T, Cheng R, Rasmussen JS, Marchese A, Zastawny R, Heng HH, Tsui LC and Shi $X$ et al.. (1995) The cloning and chromosomal mapping of two novel human opioidsomatostatin-like receptor genes, GPR7 and GPR8, expressed in discrete areas of the brain. Genomics 28: 84-91 [PMID:7590751]

18. Patra MC, Maharana J, Dehury B and De S. (2014) Computational insights into the binding mechanism of antagonists with neuropeptide B/W receptor 1. Mol Biosyst 10: 2236-46 [PMID:24938207]

19. Samson WK, Baker JR, Samson CK, Samson HW and Taylor MM. (2004) Central neuropeptide B administration activates stress hormone secretion and stimulates feeding in male rats. $J$ Neuroendocrinol. 16: 842-849 [PMID:15500544]

20. Shimomura $Y$, Harada M, Goto M, Sugo T, Matsumoto Y, Abe M, Watanabe T, Asami T, Kitada C and Mori $M$ et al.. (2002) Identification of neuropeptide $W$ as the endogenous ligand for orphan G-proteincoupled receptors GPR7 and GPR8. J. Biol. Chem. 277: 35826-32 [PMID:12130646]

21. Singh G, Maguire JJ, Kuc RE, Fidock M and Davenport AP. (2004) Identification and cellular localisation of NPW1 (GPR7) receptors for the novel neuropeptide W-23 by [125I]-NPW radioligand binding and immunocytochemistry. Brain Res. 1017: 222-6 [PMID:15261118]

22. Tanaka H, Yoshida T, Miyamoto N, Motoike T, Kurosu H, Shibata K, Yamanaka A, Williams SC, Richardson JA and Tsujino $\mathrm{N}$ et al.. (2003) Characterization of a family of endogenous neuropeptide ligands for the G protein-coupled receptors GPR7 and GPR8. Proc. Natl. Acad. Sci. U.S.A. 100: 6251-6 [PMID:12719537]

23. Taylor MM, Yuill EA, Baker JR, Ferri CC, Ferguson AV and Samson WK. (2005) Actions of neuropeptide W in paraventricular hypothalamus: implications for the control of stress hormone secretion. Am. J. Physiol. Regul. Integr. Comp. Physiol. 288: R270-5 [PMID:15345475]

24. Watanabe N and Yamamoto M. (2015) Neural mechanisms of social dominance.Front Neurosci 9: 154 [PMID:26136644]

25. Yamamoto T, Saito O, Shono K and Tanabe S. (2005) Anti-hyperalgesic effects of intrathecally administered neuropeptide W-23, and neuropeptide B, in tests of inflammatory pain in rats. Brain Res. 1045: 97-106 [PMID:15910767]

26. Zaratin PF, Quattrini A, Previtali SC, Comi G, Hervieu G and Scheideler MA. (2005) Schwann cell overexpression of the GPR7 receptor in inflammatory and painful neuropathies. Mol. Cell. Neurosci. 28: 55-63 [PMID:15607941] 